\title{
DEVELOPMENT OF ENVIRONMENT FRIENDLY KILNS FOR PRODUCTION OF CHARCOAL
}

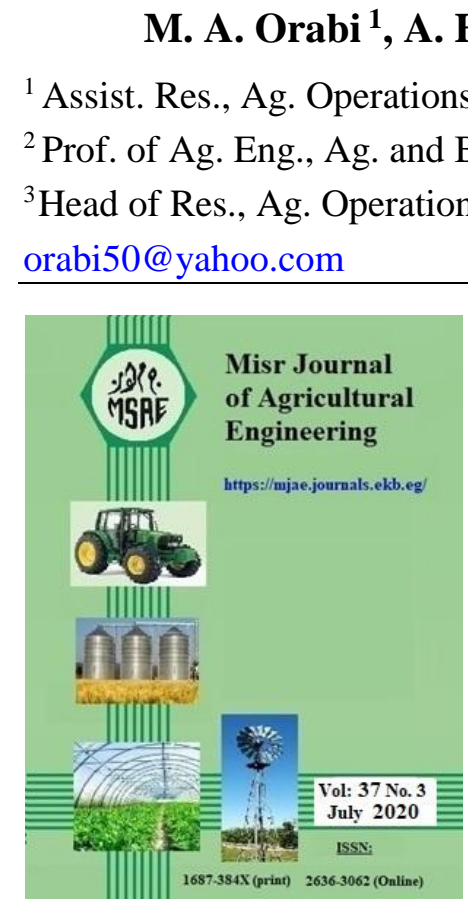

(C) Misr J. Ag. Eng. (MJAE)

\section{Keywords:}

charcoal, kiln, emission treatment, fixed carbon, volatile matter, ash-content.

\begin{abstract}
The aim of this study is to develop an environment friendly kiln to reduce emissions and the energy used in the operation of carbonization. The studied factors are two types of wood were used namely "casuarina and citrus" with different moisturecontents of 6.8 and $13.1 \%$ at pyrolysis temperatures of 300 , 350,400 and $450{ }^{\circ} \mathrm{C}$. The main results in this study can be summarized in the following points: The maximum charcoal yield of $50.38 \%$ was obtained with casuarina wood moisture-content of $6.8 \%$ and kiln temperature of $300{ }^{\circ} \mathrm{C}$. Meanwhile, the minimum charcoal yield of $32.14 \%$. was obtained with wood moisture-content of $13.08 \%$ and kiln temperature of $450{ }^{\circ} \mathrm{C}$. The maximum $\mathrm{CO}_{2}$ of $17082 \mathrm{mg} / \mathrm{m}^{3}$ was obtained using emission treatment by burning at kiln temperature of $350{ }^{\circ} \mathrm{C}$. Moreover, the minimum $\mathrm{CO}_{2}$ of $2044.8 \mathrm{mg} / \mathrm{m}^{3}$ was obtained using emission treatment by burning and chemicals at kiln temperature of $50{ }^{\circ} \mathrm{C}$. The maximum $\mathrm{CO}$ of $1859.3 \mathrm{mg} / \mathrm{m}^{3}$ was obtained without emission treatment at kiln temperature of $350{ }^{\circ} \mathrm{C}$. Moreover, the minimum $\mathrm{CO}$ of $156.9 \mathrm{mg} / \mathrm{m}^{3}$ was obtained using emission treatment by burning and chemicals at kiln temperature of $50{ }^{\circ} \mathrm{C}$. The highest charcoal production-cost of 9.84 L.E. $/ \mathrm{kg}$ of was obtained by using "burning + chemical" emissions-treatment at kiln temperature of $450{ }^{\circ} \mathrm{C}$ and moisture content of $13.08 \%$. Meanwhile, the minimum production cost of 3.21 L.E. $/ \mathrm{kg}$ was obtained by using burning emissions-treatment of kiln temperature of $300{ }^{\circ} \mathrm{C}$ and moisture content of $6.8 \%$.
\end{abstract}

\section{INTRODUCTION}

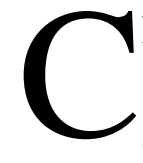
harcoal is a solid bio fuel obtained from biomass by means of a chemical process known as "pyrolysis" or simply as "carbonization process". Charcoal consists of the thermal decomposition of biomass in the absence of oxygen. Egypt rank $11^{\text {th }}$ level in the world in the charcoal exportation. Exporting of charcoal adds about 11 million dollars to Egyptian income. There are about 5000 traditional earth-mound kilns in different places of the Egyptian governorates, which have about two million workers. Seventy percent of charcoal which 
produced from fruit-wood exported to Arab countries and the other $30 \%$ of charcoal exported to Europe and Asia (Ministry of Environment, 2015). Egypt produces about 1.445 million tons of charcoal. About 1.425 million tons of charcoal were consumed by a local market. About 21 million tons were exported (FAO, 2017).

Foley et al. (2001) reported that the ash content of high-quality charcoal was reported between $0.5-5 \%$, resulting in a range of thermal values between $28-33 \mathrm{MJ} / \mathrm{kg}$. Kaale (2005) found that charcoal has a higher thermal value per unit weight of firewood of about $31.8 \mathrm{MJ} / \mathrm{kg}$ of fully carbonized charcoal with a moisture content of about $5 \%$ compared to about $16 \mathrm{MJ} / \mathrm{kg}$ of firewood with moisture content of about $15 \%$ on a dry basis. Delmas et al. (1991) reported that emissions from natural charcoal production increase about 10 times higher than standard wood burning. Gomaa and Fathi (2010) measured the temperature of the carbonate operation based on a percentage of the products of combustible gases. It was found that the analysis of the advanced gases was: $\mathrm{CO}: 25 \%, \mathrm{CO}_{2}: 15 \%, \mathrm{O}_{2}: 5 \%, \mathrm{CH}_{4}: 4.5 \%, \mathrm{H}_{2}: 2 \%, \mathrm{C}_{2} \mathrm{H}_{6}: 1 \%, \mathrm{~N}_{2}$ : $47.5 \%$. Mugo and Gathui (2010) evaluated four types of kilns are mainly used in charcoal production, these include; traditional earth kilns efficiently $10-15 \%$, improved earth kilns $24-30 \%$, construction kilns $28-30 \%$ and metal kilns efficiently $19-30 \%$. The financial potential of the charcoal product and kilns ability directly affect the choice of the kiln used.

Keita (2010) found that the value of wood heating in general is about $3500 \mathrm{kcal} / \mathrm{kg}$ for green wood and 4500 - $4770 \mathrm{kcal} / \mathrm{kg}$ for dry wood. Charcoal, however, the heating value near 7500 $\mathrm{kcal} / \mathrm{kg}$. Reumerman and Frederiks (2012) defined the traditional production process in open pit or furnaces, as implemented in rural areas, is ineffective. Weight efficiency of $10-15 \%, 7$ - $10 \mathrm{~kg}$ of wood to produce one kilogram of charcoal. Depending on the sustainability of timber used in the charcoal industry, emissions of greenhouse gases emitted into the atmosphere may be large at the global level. Emission gases in year 2018, which produced from charcoal, were about 250.7 million ton of carbon dioxide (CAPMAS, 2019).

The emissions of traditional charcoal kilns and the pyrolysis of wood cause an excess methane $\left(\mathrm{CH}_{4}\right)$ and carbon dioxide $\left(\mathrm{CO}_{2}\right)$ and the concentration over average ambient air is about $12 \%$ (Adam., 2009). The traditional charcoal-kilns have some disadvantages such as more energy consuming, needing more carbonization-time, and producing more emissions, therefore, the aim of this work is to develop a kiln for charcoal production with high charcoal quality, less cost and low emission.

\section{MATERIALS AND METHODS}

Designed kiln for charcoal production: Figs. 3.1 and 3.2 show the photographs, isometric and views of designed kiln. The designed kiln consists of the following parts:

The main frame of the designed kiln was made of steel sheets with $3 \mathrm{~mm}$ thickness. The main frame consists of three parts:

(a) Charcoal production-unit body: the charcoal production-unit has height of $105 \mathrm{~cm}$ and diameter of $75 \mathrm{~cm}$. The main frame consists of two parts:

1- Carbonization chamber: The carbonization chamber consists of two internal cylinders with a diameter of $65 \mathrm{~cm}$ and an external cylinder with $75 \mathrm{~cm}$ diameter with height of $80 \mathrm{~cm}$. There is a rock wool (isolation) layer with $10 \mathrm{~cm}$ thickness between two cylinders to prevent the heat transfer between them. 
2- Fire chamber: The fire chamber consists of internal and external cylinders with diameters of 65 and $75 \mathrm{~cm}$ with height of $20 \mathrm{~cm}$. A rock-wool (isolation) layer with $10 \mathrm{~cm}$ thickness was installed between the two cylinders to prevent the heat transfer between them

(b) Processing unit control-unit body. The processing unit has length of $75 \mathrm{~cm}$, width of 25 $\mathrm{cm}$ and height of $25 \mathrm{~cm}$. Treatment unit used to treat emissions by three stages. The three stages of treatment are passing the emissions in water, life limestone solution and chemical additives $(\mathrm{NaOH}$ and $\mathrm{CaOH})$ respectively.

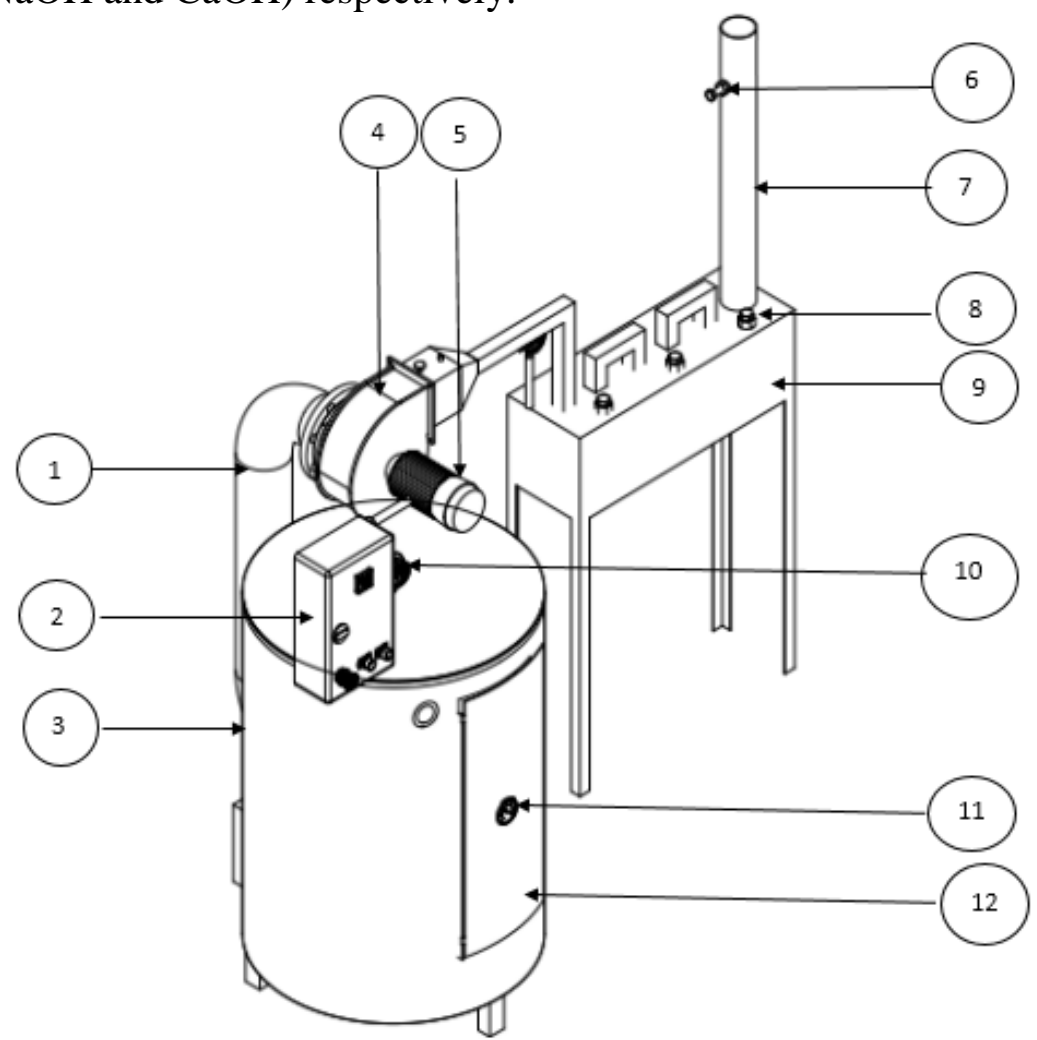

(1) Emission suction-pip, (2) Control unit, (3) Kiln body, (4) Suction fan, (5) Motor, (6) Emissionsensing opening, (7) Chimney, (8) Additives opening, (9) Emission processing-unit, (10) Pressure gauge, (11) Thermometer and (12) kiln door opening.

Fig.1: Photograph of the designed kiln for charcoal production.

(c) control-unit box. The control unit has length of $30 \mathrm{~cm}$, width of $15 \mathrm{~cm}$ and height of 40 $\mathrm{cm}$. Control unit used to control of temperature of kiln, connect, and disconnect of the motor.

(d) Electrical motor: Electrical motor single-phase induction motor of with $0.375 \mathrm{~kW}(0.5$ $\mathrm{hp}$ ) and $2850 \mathrm{r} \mathrm{p}$ m was used to operate the suction fan.

\section{Instrumentations:}

Emission measurement devices: Emission measurement devices were used to measure the emission. Estimated emissions were monoxide carbon $(\mathrm{CO})$ and carbon dioxide $\left(\mathrm{CO}_{2}\right)$. The specifications of the emission measurement devices were shown in Table 1and Fig 3.

\section{Methods:}

The field experiments: were carried out at "Ezbet Amr" Village, "Ashmoon", Menoufia Governorate during the years of 2018 and 2019. 


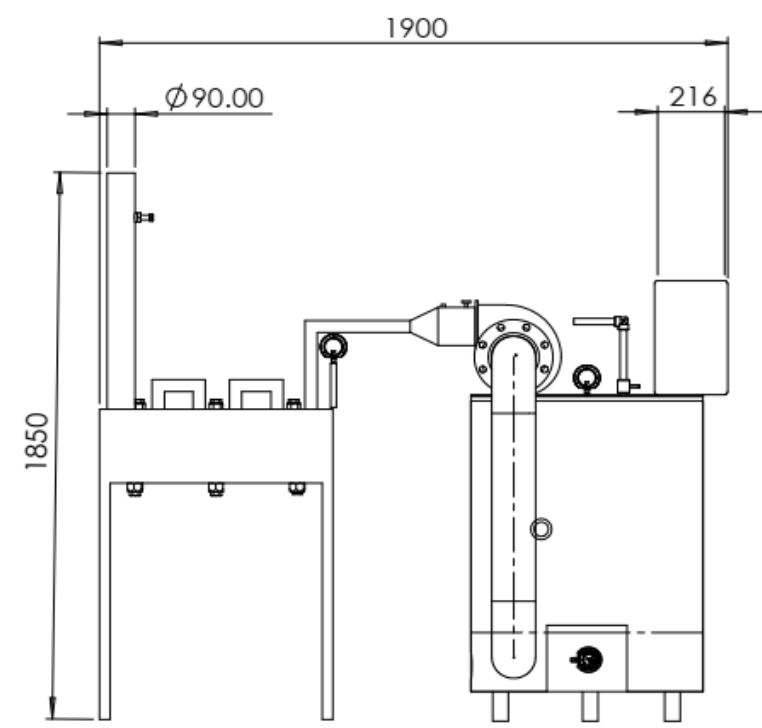

Elevation

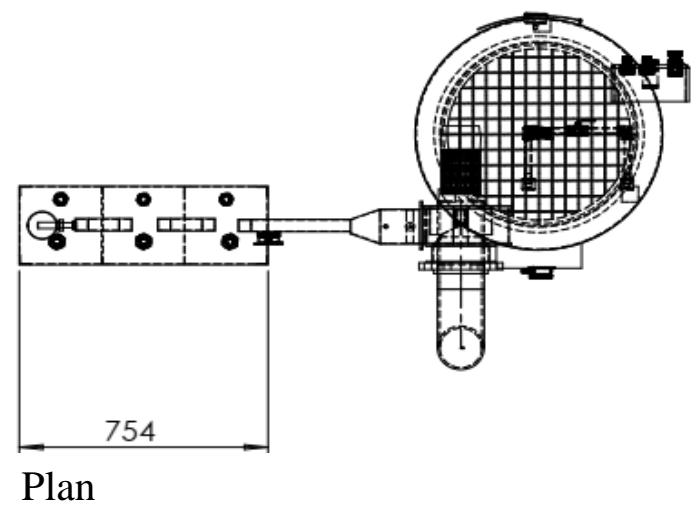

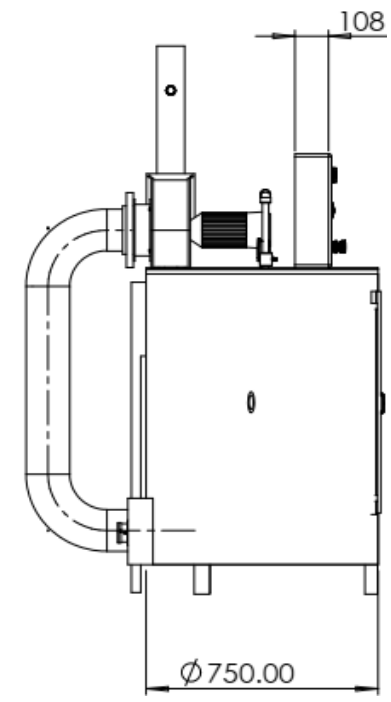

Side view

Fig. 2: Views of the designed kiln for charcoal production.

Table 1: Specifications of the automobile emission analyzer.

\begin{tabular}{|c||c|c|}
\hline \multicolumn{1}{|c||}{ Items } & \multicolumn{2}{c|}{ Values } \\
\hline \hline Made in & Chine & Chine \\
\hline \hline Model & $\mathrm{AZ7752}$ & UT337A \\
\hline \hline Measure & $\mathrm{CO}_{2}$ & $\mathrm{CO}$ \\
\hline \hline Range & $0: 9999 \mathrm{ppm}$ & $0: 1000 \mathrm{ppm}$ \\
\hline \hline Resolution & $1 \mathrm{ppm}$ & $1 \mathrm{ppm}$ \\
\hline Dimensions, mm. & $205(\mathrm{~L}) \times 70(\mathrm{~W}) \times 56(\mathrm{D})$ & $197(\mathrm{~L}) \times 55(\mathrm{~W}) \times 34(\mathrm{D})$ \\
\hline \hline Weight & $220 \mathrm{~g}$ & $140 \mathrm{~g}$ \\
\hline Power & $(1.5 \mathrm{~V})$ Battery & $(1.5 \mathrm{~V})$ Battery \\
\hline
\end{tabular}

\section{Tested parameters.}

The tested parameters of kiln performance were:

1- Type of wood: casuarina-tree blocks with mean dimensions of 5 × 5 × $20 \mathrm{~cm}$ and citrus branches with diameter range of $3-6 \mathrm{~cm}$.

2- Pyrolysis temperature: Pyrolysis temperatures were $300,350,400$ and $450^{\circ} \mathrm{C}$ were tested. The tested temperature range was chosen according to Rautiainen, 2014.

3- Method of emissions treatment: Burning, "burning and chemicals" and without emission treatment methods were tested. 


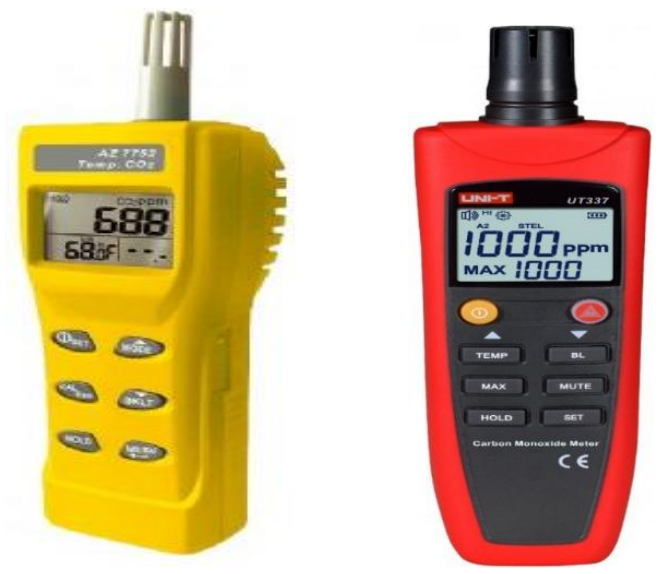

Fig. 3: Photograph of the emission measurement devices.

\section{Measurements:}

In The performance of designed kiln was tested by measure the following items:

1- Charcoal yield, kiln productivity, carbonization time and costs were measured using casuarina wood at all tested moisture contents and temperatures.

2- Emissions of kiln: Emissions of kiln were measured at sensing openings of chimney, suction fan and cooling pipe using casuarina wood with moisture content of $6.8 \%$ at all tested temperatures and treatment methods. The emissions were measured by devices $\mathrm{CO}_{2}$ meter model of "AZ 7752" and CO meter model of "UT337A". To convert concentration in ppm to $\mathrm{mg} / \mathrm{m}^{3}$, the following equation was used at constant atmosphere pressure of 1 bar and air temperature of $25^{\circ} \mathrm{C}$ (Terrie., 2006):

Concentration $\left(\mathrm{mg} / \mathrm{m}^{3}\right)=\frac{\text { concentration }(\mathrm{ppm}) \times \text { molecular weight }}{24.45}$.

Where:

Molecular weight for $\mathrm{CO}_{2}=44.01 \mathrm{~g} / \mathrm{mol}$ and Molecular weight for $\mathrm{CO}=28.01 \mathrm{~g} / \mathrm{mol}$.

\section{Charcoal yield.}

The charcoal yield was determined by using the following equation (Ronsse et al., 2013):

Charcoal yield, $\%=\frac{\mathrm{M}_{\mathrm{CH}}}{\mathrm{M}_{\mathrm{wO}}} \quad \times 100$

Where:

$\mathrm{M}_{\mathrm{CH}}$ : Mass of charcoal, $\mathrm{kg}$ and $\mathrm{M}_{\mathrm{wO}}$ : Mass of wood, $\mathrm{kg}$.

\section{Kiln productivity.}

The kiln productivity was calculated by using the following equation (Mady, 1999):

Productivity, $\mathrm{kg} / \mathrm{h}=\quad \frac{\mathrm{w}}{\mathrm{t}}$

Where:

W: Charcoal mass of kiln output, kg and T: Operating time, h.

\section{Power requirements:}

The power requirement was estimated by using the clamp meter to measure the line current strength and the potential difference value. The total electric power requirement $\mathrm{u}$ was calculated according to "Kurt, 1979" by the following equation:

$$
\mathrm{P}=(\mathrm{I} \times \mathrm{V} \times \operatorname{Cos} \theta) / 1000 \text {. }
$$

Where: 
P: Power requirement, kW, I: Line current strength, Amperes, V: Potential difference, Voltage and $\operatorname{Cos} \theta$ : Power factor, equal 0.8 .

Estimating the costs of using the kiln: Cost of operation was calculated according to the equation given by Awady (1978), in the following form:

$$
\mathrm{C}=\mathrm{p} / \mathrm{h}(1 / \mathrm{a}+\mathrm{i}+\mathrm{t} / 2+\mathrm{r})+(\mathrm{Ec} * \mathrm{Ep})+\mathrm{m} / 144
$$

Where:

$\mathrm{C}=$ hourly cost, $\mathrm{p}=$ price of kiln, $\mathrm{h}=$ yearly working hours, $\mathrm{a}=$ life expectancy of the machine, $\mathrm{i}=$ interest rate/year, $\mathrm{t}=$ taxes, $\mathrm{r}=$ overheads and indirect cost ratio, $\mathrm{Ec}=$ Electricity consumption $\mathrm{kW} . \mathrm{h} / \mathrm{h}, \mathrm{Ep}=$ Electricity price L.E/kW.h, "144" are estimated monthly working hours. *Notice that all units have to be consistent to result in L.E/h.

\section{RESULTS AND DISCUSSION}

\section{Effect of moisture-content and kiln temperature on charcoal yield}

Fig. 5 shows the effect of moisture-content of casuarina wood and kiln temperature on charcoal yield. The maximum charcoal yield of $50.38 \%$ was obtained with wood moisture content of $6.8 \%$ and kiln temperature of $300{ }^{\circ} \mathrm{C}$. Meanwhile, the minimum charcoal yield of $32.14 \%$. was obtained with wood moisture-content of $13.08 \%$ and kiln temperature of $450{ }^{\circ} \mathrm{C}$. The decreasing of charcoal yield by increasing wood moisture-content and kiln temperature is due decreasing the mass of produced charcoal. Multiple regression analysis was carried out to obtain a relationship between charcoal yield data as a function of both wood moisture-content and kiln temperature. The following multiple prediction equation was obtained:

$\mathrm{E}_{\mathrm{k}}=\frac{1650.77}{\mathrm{M} \mathrm{C}^{0.362} * \mathrm{~T}^{0.483}}$

$\left(\mathrm{R}^{2}=0.993\right)$

Where: $\mathrm{E}_{\mathrm{k}}$ : charcoal yield, \%., M.C: Wood moisture-content, $\%$ and $\mathrm{T}_{\mathrm{c}}$ : Temperature, ${ }^{\mathrm{O}} \mathrm{C}$.

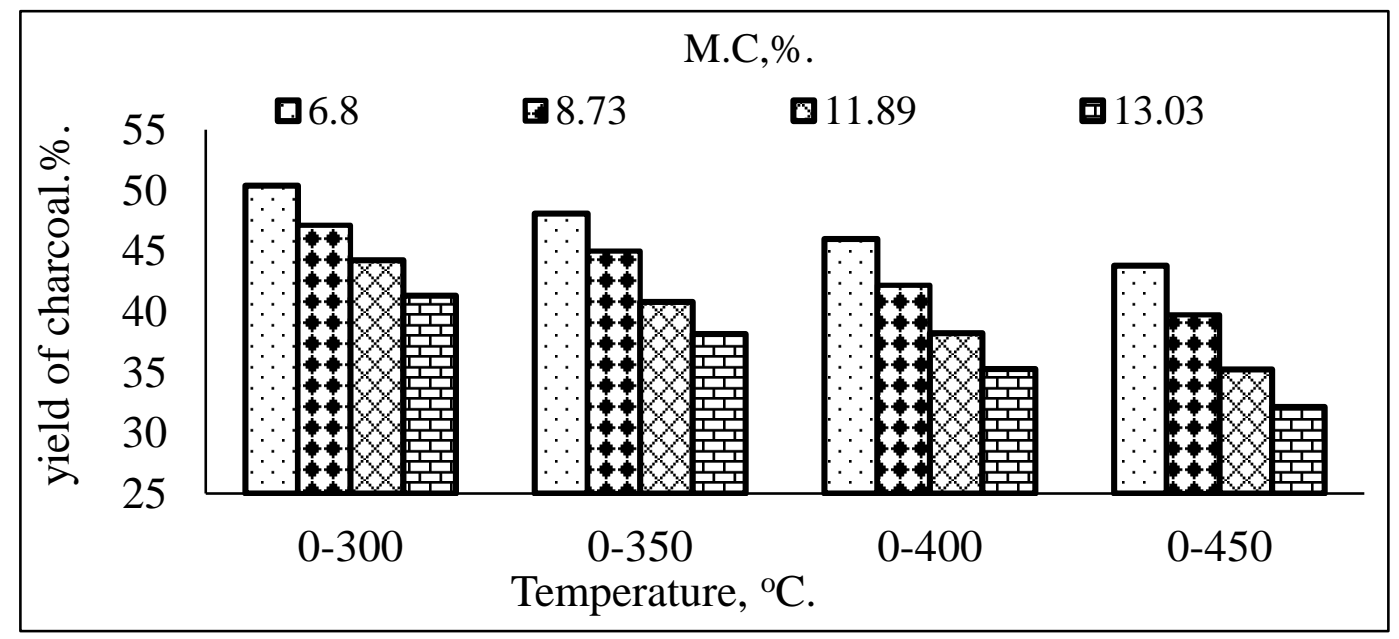

Fig. 5: Effect of wood moisture-content and kiln temperature on charcoal yield.

Effect of wood moisture-content, kiln temperature and emissions-treatment on carbonization time.

Figs. 6 and 7 show that the increasing kiln temperature from 300 to $400{ }^{\circ} \mathrm{C}$ the carbonizationtime range increased from $7-12$ to $10.45-15.4 \mathrm{~h}$ at all tested wood moisture-contents with emissions burning. 
By increasing wood moisture-content from 6.8 to $13.08 \%$ the carbonization time range increased from $7-10.45$ to $12-15.4 \mathrm{~h}$ at all tested kiln-temperatures with emissions burning. At wood moisture-content of $6.8 \%$, by increasing kiln temperature from 300 to $450{ }^{\circ} \mathrm{C}$ the carbonization times were increased from 7 to $10.45 \mathrm{~h}$ and from 9.15 to $13.3 \mathrm{~h}$ by increasing kiln temperature from 300 to $450{ }^{\circ} \mathrm{C}$ with and without burning of emissions respectively.

At wood moisture-content of $6.8 \%$, the results show that the carbonization time without emissions burning increased by $22.35 \%$ as compared with emissions burning at all tested kilntemperatures. The increasing of carbonization time by increasing wood moisture-content and kiln temperature is due to increase the time needed to get rid of moisture.

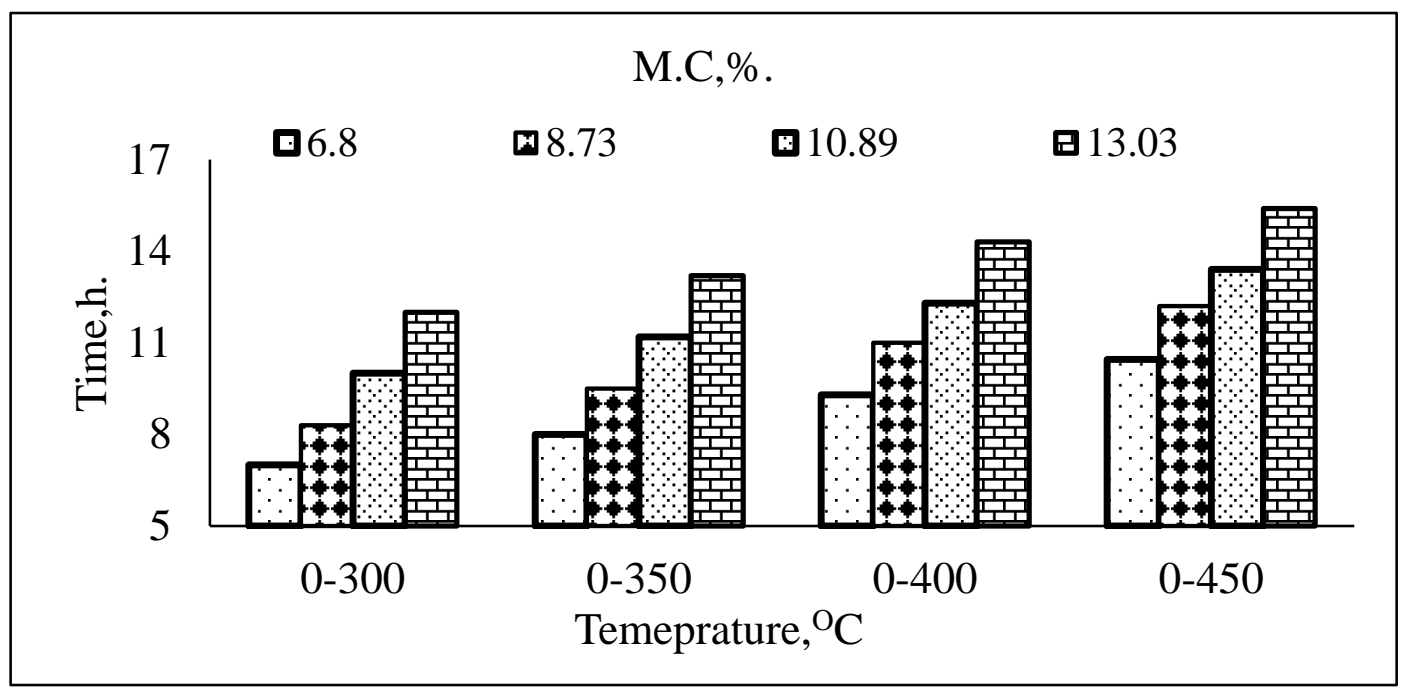

Fig. 6: Effect of wood moisture-content and kiln temperature on carbonization time with emissions burning.

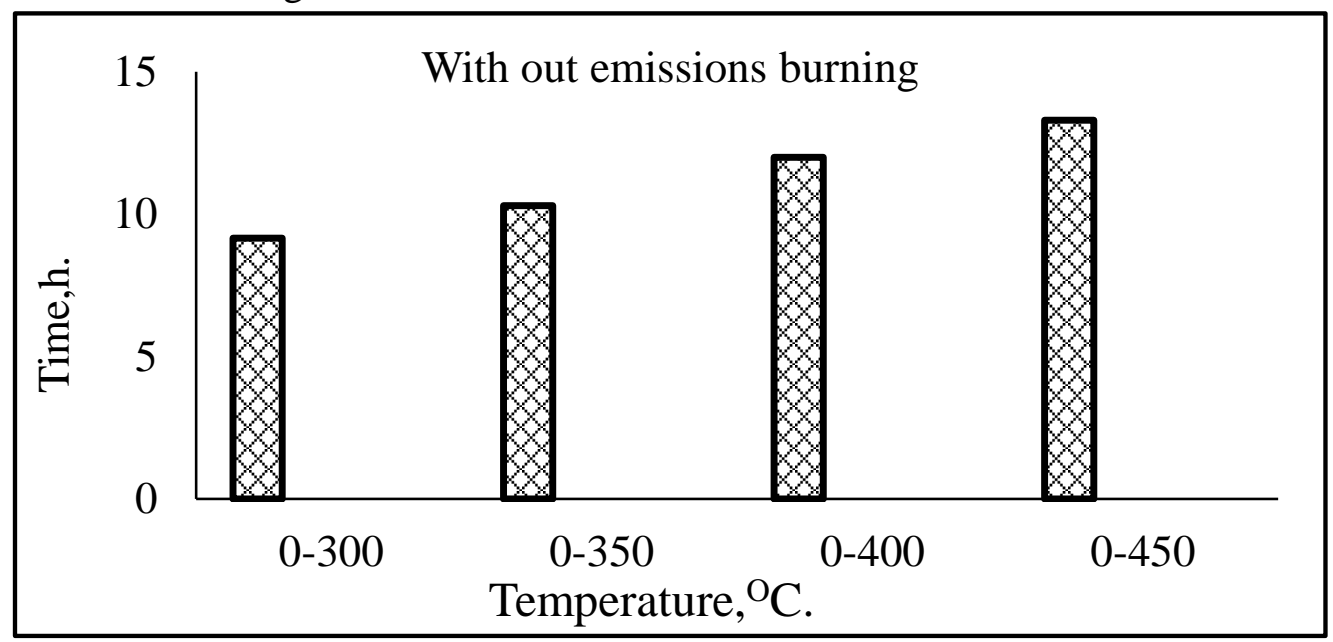

Fig. 7: Effect of kiln temperature on carbonization time at constant wood moisture-content of $6.8 \%$ and without emissions burning.

Effect of wood moisture-content and kiln temperature on kiln productivity.

Fig. 8 shows the effect of wood moisture-content and kiln temperature on kiln productivity. The maximum kiln-productivity of $7.20 \mathrm{~kg} / \mathrm{h}$ was obtained with wood moisture content of 6.8 $\%$ and kiln temperature of $300{ }^{\circ} \mathrm{C}$. Meanwhile, the minimum kiln-productivity of $2.10 \mathrm{~kg} / \mathrm{h}$. was obtained with wood moisture-content of $13.08 \%$ and kiln temperature of $450{ }^{\circ} \mathrm{C}$. Date 
show that by increasing kiln temperature from 300 to 450 the kiln productivity decreased by $41.35 \%$ at all tested wood moisture-contents. The decreasing of kiln productivity by increasing wood moisture-content and kiln temperature is due to decreasing the produced mass of charcoal. Multiple regression analysis was carried out to obtain a relationship between kiln-productivity data as a function both of wood moisture-content and kiln temperature. The following multiple prediction equation was obtained:

$$
\operatorname{Pr}=\frac{87733}{M C^{1.02} \times T^{1.31}} \quad\left(R^{2}=0.976\right)
$$

Where: Pr: kiln productivity, kg/h, M.C: Wood moisture-content, $\%$ and $\mathrm{T}_{\mathrm{c}}$ : Temperature, ${ }^{\mathrm{O}} \mathrm{C}$.

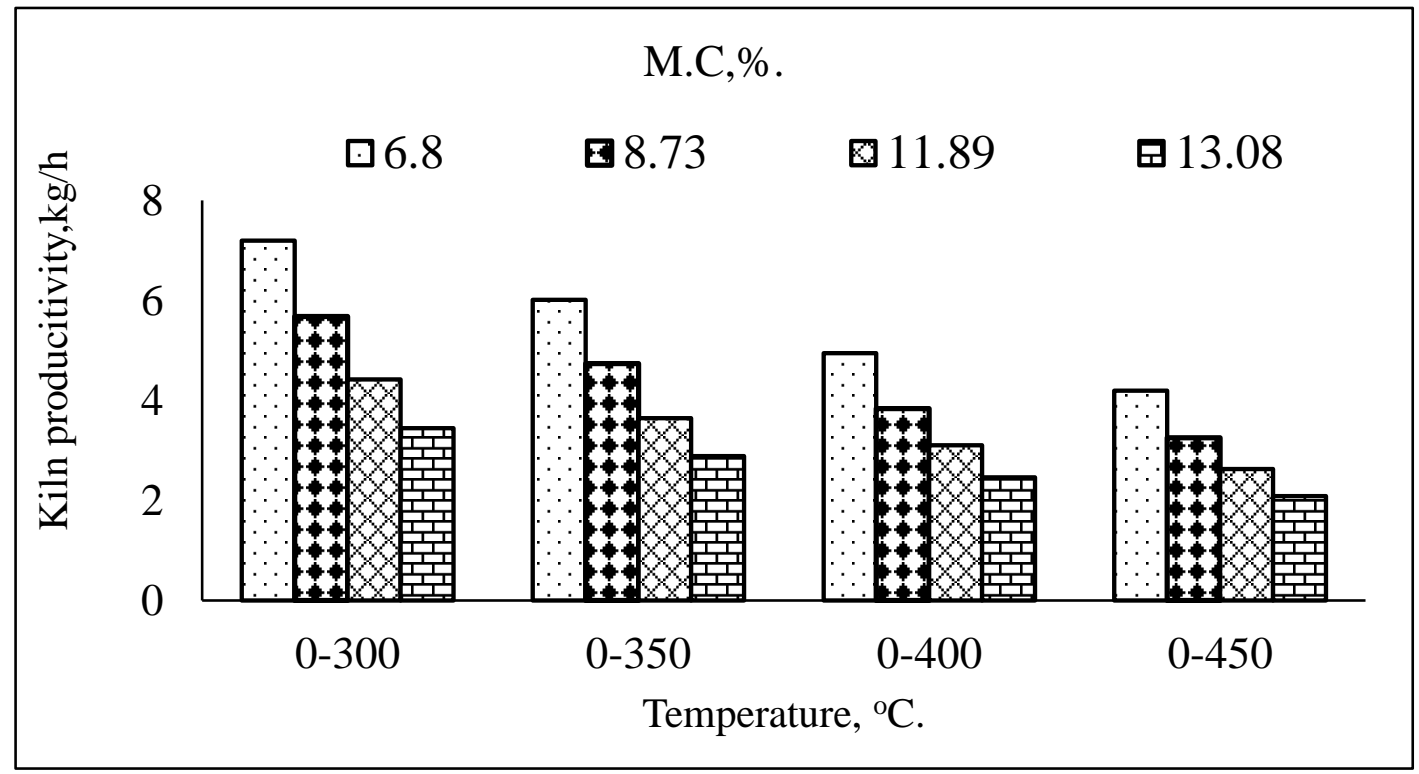

Fig. 8: Effect of moisture-content and temperature on kiln productivity.

\section{Effect of kiln temperature and emissions-treatment on carbon dioxide and monoxide $\left(\mathrm{CO}_{2}\right.$ and $\mathrm{CO}$ ) percent.}

Fig. 9 shows the effect of kiln temperature and emissions-treatment on $\mathrm{CO}_{2}$ and $\mathrm{CO}$ percent for casuarina wood.

\section{(a) $\mathrm{CO}_{2}$.}

The maximum $\mathrm{CO}_{2}$ of $17082 \mathrm{mg} / \mathrm{m}^{3}$ was obtained using emission treatment by burning at kiln temperature of $350{ }^{\circ} \mathrm{C}$. Moreover, the minimum $\mathrm{CO}_{2}$ of $2044.8 \mathrm{mg} / \mathrm{m}^{3}$ was obtained using emission treatment by burning and chemicals at kiln temperature range of $50{ }^{\circ} \mathrm{C}$. The values of $\mathrm{CO}_{2}$ without, by burning and by "burning + chemical" emission-treatments were 2269.8 $6807.6,3281.4-17082$ and $2044.8-2860.2 \mathrm{mg} / \mathrm{m}^{3}$ respectively at all tested kiln-temperatures.

(b) $\mathrm{CO}$.

The maximum CO of $1859.3 \mathrm{mg} / \mathrm{m}^{3}$ was obtained using emission treatment by without emission treatment at kiln temperature of $350{ }^{\circ} \mathrm{C}$. Moreover, the minimum $\mathrm{CO}$ of $156.9 \mathrm{mg} / \mathrm{m}^{3}$ was obtained using emission treatment by burning and chemicals at kiln temperature of $50{ }^{\circ} \mathrm{C}$. Results were obtained using the method of treating emissions by burning and chemical from 156.9 to 591.1 at different temperature under study. According to (ES: 6122/2008). 


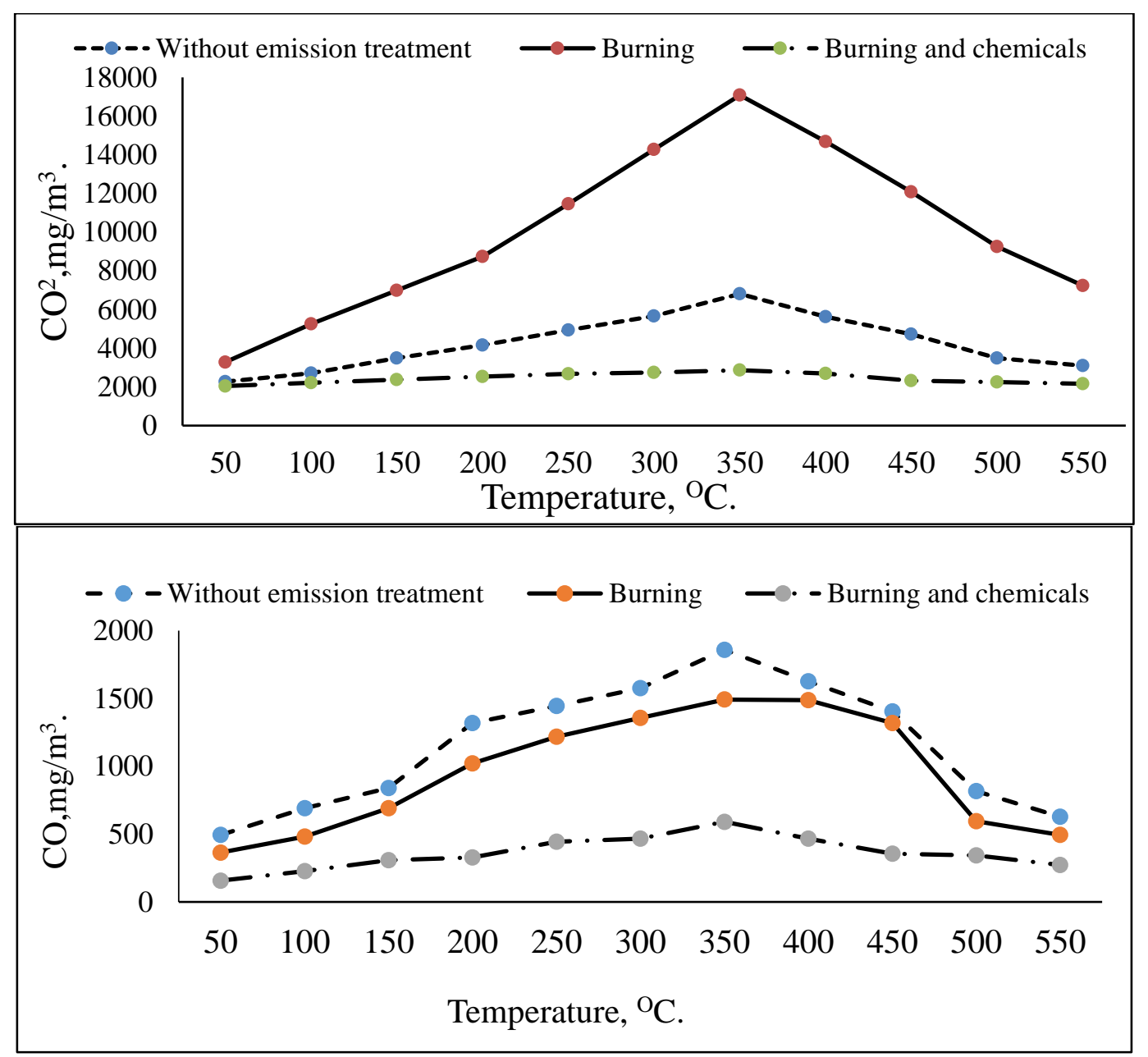

Fig. 9: Effect of kiln temperature and emissions-treatment on $\mathrm{CO}_{2}$ and $\mathrm{CO}$ for casuarina wood.

The values of CO without, by burning and by "burning + chemical" emission-treatments were 493.7 - 1859.3, 364.3 - 14912.6 and $156.9-705.7 \mathrm{mg} / \mathrm{m}^{3}$ respectively at all tested kiln temperatures. Without emissions treatment, the increased of $\mathrm{CO}_{2}$ and $\mathrm{CO}$ by increasing kiln temperature from 100 to $350{ }^{\circ} \mathrm{C}$ is due to increasing of fixed carbon. Moreover, decreasing of $\mathrm{CO}_{2}$ and $\mathrm{CO}$ by increasing kiln temperature from 350 to $450{ }^{\circ} \mathrm{C}$ is due to thermal decomposition of whole cellulose, which release the $\mathrm{CO}_{2}$ and $\mathrm{CO}$ by burning. In addition to, if wood is heated under lack of oxygen conditions, the chemical process is then the incomplete combustion with carbon monoxide formation:

$\mathrm{C}+1 / 2 \mathrm{O}_{2}=\mathrm{CO}$.

On other hand, emission treatment by burning, $\mathrm{CO}_{2}$ increased by increasing kiln temperature from 50 to $350{ }^{\circ} \mathrm{C}$ because of the following reasons:

- Each $\mathrm{kg}$ of methane burnt results in $2.75 \mathrm{Kg}$ of carbon dioxide.

- For every fixed amount of carbon burned, a fixed amount of carbon dioxide and monoxide are produced.

- Organics and $\mathrm{CO}$ are naturally combusted to $\mathrm{CO}_{2}$

Cost of using the developed charcoal kiln for charcoal production.

Table 2 shows the total costs of using the developed kiln for charcoal production. The maximum production cost of 9.84 L.E./kg was obtained by using "burning + chemical" emissionstreatment at kiln temperature of $450{ }^{\circ} \mathrm{C}$ and moisture content of $13.08 \%$. Meanwhile, the 
minimum production cost of 3.21L.E./kg was obtained by using burning emissions-treatment of kiln temperature $300{ }^{\circ} \mathrm{C}$ and moisture content of $6.8 \%$.

The operation and production costs according to prices of year 2019 were 12.93 L.E./h and 5.35 L.E./kg at optimum conditions of kiln operation at moisture-content $6.8 \%$ and temperature 450 ${ }^{\mathrm{O}} \mathrm{C}$

Table 2: Effect of moisture content and kiln temperature on operation and production costs.

\begin{tabular}{|c|c|c|c|c|c|c|c|c|c|}
\hline \multirow{3}{*}{$\begin{array}{l}\text { Emissions- } \\
\text { treatment }\end{array}$} & \multirow{3}{*}{$\begin{array}{c}\text { Moisture } \\
\text { content, } \\
\% .\end{array}$} & \multicolumn{4}{|c|}{$\begin{array}{c}\text { Productivity, } \\
\mathrm{kg} / \mathrm{h} .\end{array}$} & \multicolumn{4}{|c|}{$\begin{array}{l}\text { Production cost, } \\
\text { L.E. } / \mathrm{kg} .\end{array}$} \\
\hline & & \multicolumn{4}{|c|}{ Kiln temperature, ${ }^{\circ} \mathrm{C}$. } & \multicolumn{4}{|c|}{ Kiln temperature, ${ }^{\circ} \mathrm{C}$. } \\
\hline & & 300 & 350 & 400 & 450 & 300 & 350 & 400 & 450 \\
\hline \multirow{4}{*}{ Without } & 6.8 & 7.19 & 6.01 & 4.94 & 4.19 & 3.36 & 3.64 & 4.40 & 4.98 \\
\hline & 8.73 & 5.67 & 4.73 & 3.83 & 3.25 & 4.03 & 4.67 & 5.40 & 6.13 \\
\hline & 11.89 & 4.42 & 3.64 & 3.10 & 2.62 & 4.95 & 5.72 & 6.45 & 7.33 \\
\hline & 13.08 & 3.44 & 2.89 & 2.46 & 2.08 & 6.12 & 6.98 & 7.89 & 8.98 \\
\hline \multirow{4}{*}{ Burning } & 6.8 & 7.19 & 6.01 & 4.94 & 4.19 & 3.21 & 3.64 & 4.20 & 4.75 \\
\hline & 8.73 & 5.67 & 4.73 & 3.83 & 3.25 & 3.84 & 4.39 & 5.15 & 5.84 \\
\hline & 11.89 & 4.42 & 3.64 & 3.10 & 2.62 & 4.70 & 7.99 & 6.14 & 6.99 \\
\hline & 13.08 & 3.44 & 2.89 & 2.46 & 2.08 & 5.79 & 6.62 & 7.50 & 8.98 \\
\hline \multirow{4}{*}{$\begin{array}{l}\text { Burning + } \\
\text { Chemicals }\end{array}$} & 6.8 & 7.19 & 6.01 & 4.94 & 4.19 & 3.56 & 4.05 & 4.70 & 5.35 \\
\hline & 8.73 & 5.67 & 4.73 & 3.83 & 3.25 & 4.28 & 4.91 & 5.80 & 6.61 \\
\hline & 11.89 & 4.42 & 3.64 & 3.10 & 2.62 & 5.27 & 8.68 & 6.94 & 7.94 \\
\hline & 13.08 & 3.44 & 2.89 & 2.46 & 2.08 & 6.52 & 7.49 & 8.51 & 9.84 \\
\hline
\end{tabular}

CONCLUSION

The optimum conditions of using the developed kiln were moisture content of $6.81 \%$, kiln temperature of $450{ }^{\circ} \mathrm{C}$ and using "burning + chemical" emissions-treatment. The results at optimum previous-parameters were: charcoal yield of $43.8 \%$, carbonization time of $10.45 \mathrm{~h}$, kiln productivity $4.191 \mathrm{~kg} / \mathrm{h}$, "CO 2 and CO" emissions of 2313 and $356.3 \mathrm{mg} / \mathrm{m}^{3}$ and charcoal production-cost of 5.35 L.E./kg.

\section{REFFERENCES}

Adam, J. C. (2009) Improved and more environmentally friendly charcoal production system using a low-cost retort-kiln (Eco-charcoal), Renewable Energy (34): 1923-1925.

Awady, M. N. (1978) Engineering of tractors and agricultural machinery, Text Bk., col. Ag, Ain-shams Univ., $5^{\text {th }}$. Ed.: 164 - 167.

CAPMAS “Central Agency for Public Mobilization and Statistics”, 2019.

Delmas, R. A., A. Marenco, J. P. Tathy, B. Cros, and J. G. Baudet. (1991). Sources and sinks of methane in the African Savanna. .96(D4):7287-99.

ES: 6122/2008. Egypt standards. Charcoal. Part1: general requirement for charcoal used as fuels. 
FAO. (2017) Food and Agriculture Organization of the United Nations Principles, criteria and indicators for sustainable charcoal production, criteria and indicators for sustainable wood fuels, P: 150-155.

Foley, G. (2001) Sustainable wood fuel supplies from the dry tropical woodlands. Washington (DC, USA): ESMAP.

Gomaa, A. H and M. Fathi (2010) A simple Charcoal Kiln for hard woods or another dense Biomass. ICEHM2000, Cairo University, Egypt: 167- 174.

Kaale, B. K. (2005). Baseline study on biomass energy conservation in Tanzania. SADC Programme for Biomass Energy Conservation (ProBEC) Report.355.

Keita, J. D. (2010) "Wood or Charcoal - which is better" Unasylva - No. 157-158 - Smallscale forest enterprises. Vol. 39, 1987/3 and 4, An international journal of forestry and forest industries, FAO - Food and Agriculture Organization of theUnited Nations, Rome.

Kurt, G. (1979) Engineering formulas, 3rd Ed., MacGraw Hill Book N. Y.

Mady, M. A. (1999) developing a manual cutting machine suitable for mechanical cutting stalks. Misr J. Agric. Eng., 16(3):449 - 459.

Mugo, F and T. Gathui (2010) Biomass energy use in Kenya. In A background paper prepared for the International Institute for Environment and Development (IIED) for an International ESPA workshop on biomass energy: 19-21.

Rautiainen, M. (2014) Torrefied and carbonized wood, fuel properties and turn of exothermic reaction. M. Sc. thesis. Forest Sciences. Dept, Agriculture and Forestry. Fact. of Engineering, Helsinki Uviv.30-36.

Reumerman, P. J and B. Frederiks (2012) Charcoal Production with Reduced Emissions, $12^{\text {th }}$ European Conference on Biomass for Energy, Industry and Climate Protection, Amsterdam.

Ronsse, F., D. Dickinson., R. Nachenius, and W. Prins. (2013). Biomass pyrolysis and bio char characterization Department of Bio systems Engineering, Faculty of Bioscience Engineering, Ghent University (Belgium) pp:1-24.

Terrie, K. B. (2006) Understanding units of measurement. Environmental Science and Technology Briefs for Citizens. 


\section{تطوير أفران صديقة للبيئة لإنتاج الفحم النباتي}

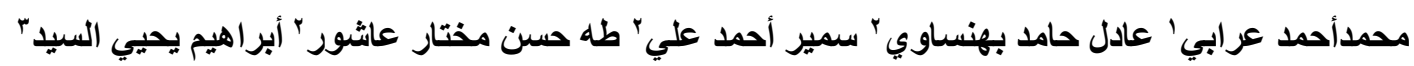

' باحث مساعد بقسم بحوث نظم ميكنة العمليات الزر اعية ـ معهد بحوث الهندسة الزر اعية بالدقي ـ الجيزة ـ مصر.

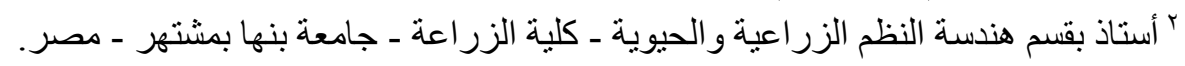

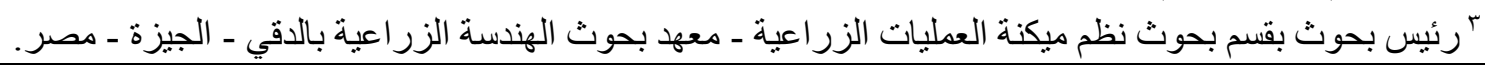

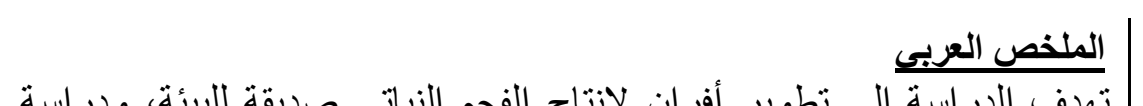

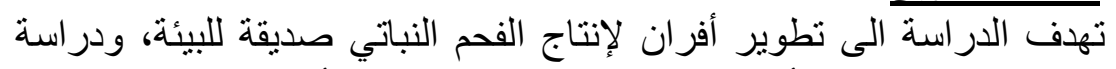

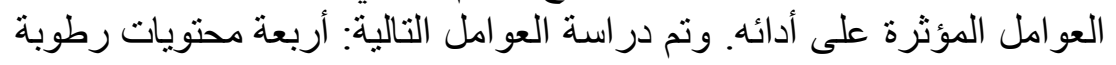

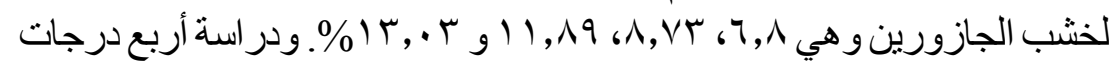

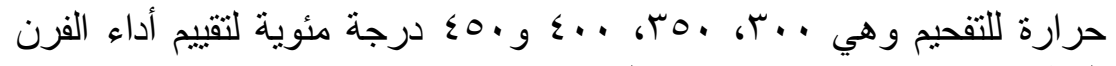

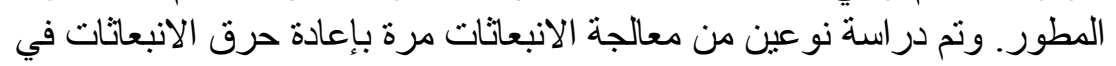

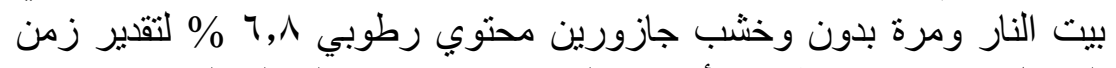

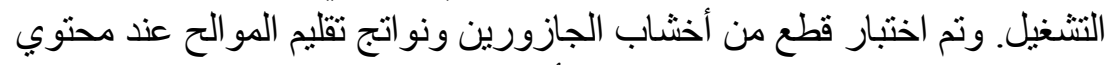

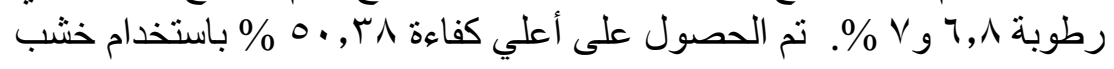

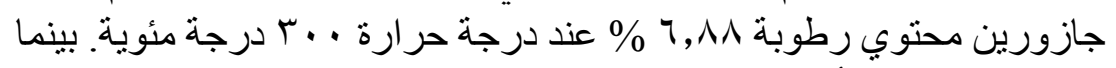

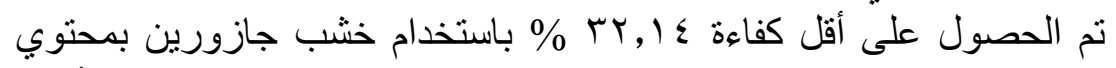

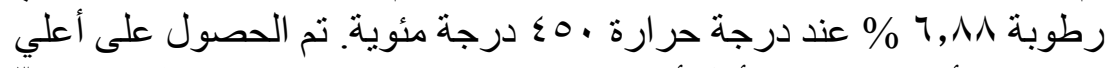

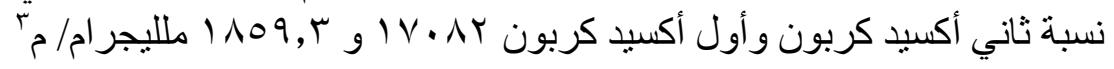

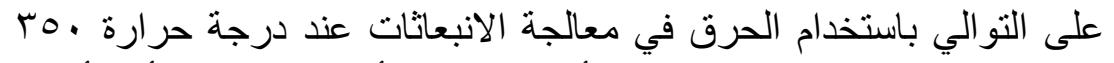

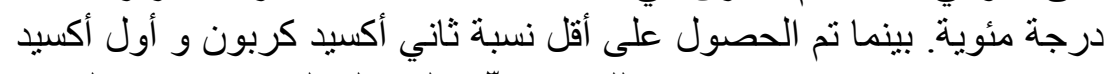

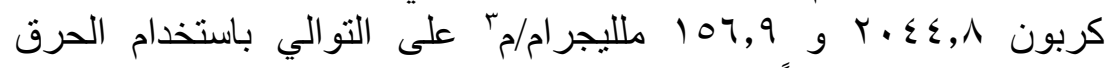

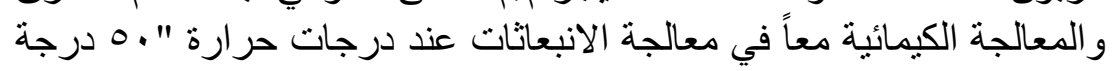

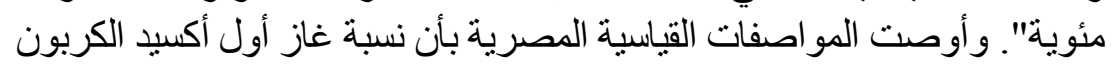

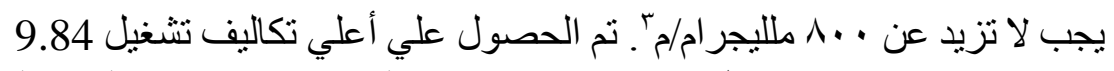

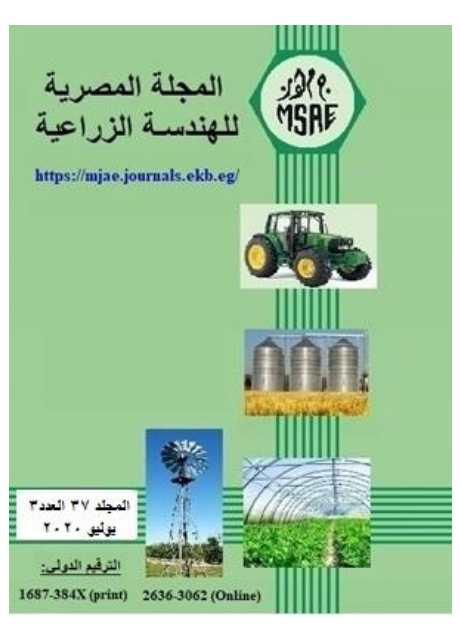

(C) المجلة المصرية للهندسة الزراعية

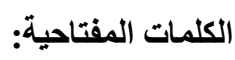

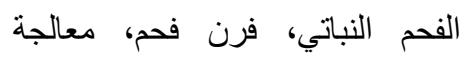

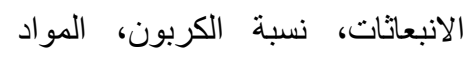

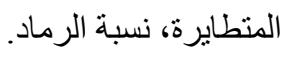

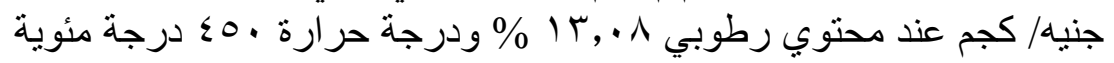

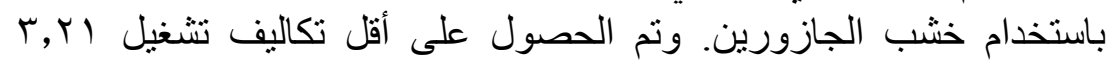

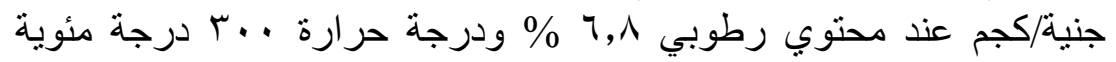
بأستخدام خشب الجازورينا. 